\section{Regards sur l'économie allemande}

Bulletin économique du CIRAC

$110 \mid 2013$

Varia

\title{
Finances publiques
}

KIRCHHOF Paul, Deutschland im Schuldensog. Der Weg vom Bürgen zurück zum Bürger

\section{(2) OpenEdition}

Journals

Édition électronique

URL : http://journals.openedition.org/rea/4603

DOI : $10.4000 /$ rea.4603

ISSN : 1965-0787

Éditeur

CIRAC

Édition imprimée

Date de publication : 15 octobre 2013

Pagination : 39

ISSN : 1156-8992

Référence électronique

"Finances publiques », Regards sur l'économie allemande [En ligne], 110 | octobre 2013, mis en ligne le 16 octobre 2013, consulté le 22 septembre 2020. URL : http://journals.openedition.org/rea/4603 ; DOI : https://doi.org/10.4000/rea.4603

Ce document a été généré automatiquement le 22 septembre 2020

(C) CIRAC 


\section{Finances publiques}

KIRCHHOF Paul, Deutschland im Schuldensog. Der Weg vom Bürgen zurück zum Bürger

\section{RÉFÉRENCE}

KIRCHHOF Paul, Deutschland im Schuldensog. Der Weg vom Bürgen zurück zum

Bürger, Verlag C.H. Beck, Munich, 2012, 310 p.

1 Le Prof. Paul Kirchhof, éminent fiscaliste et ancien juge du Tribunal constitutionnel fédéral (1987-99), prend ici pour objet la dette allemande (plus de 2000 milliards $€$ ), ainsi que les garanties accordées par l'Allemagne dans le cadre de la gestion de la crise au sein de la zone Euro. Il expertise l'origine et l'évolution de la dette, pose la question de sa conformité avec le droit constitutionnel allemand et le droit européen, et formule des propositions pour "[nous] permettre de retrouver la mesure». Plaçant le principe de démocratie au cœur de son propos, il trace ainsi «la voie de retour du garant au citoyen » (sous-titre de l'ouvrage). A lire absolument pour comprendre les jugements afférents de la Cour de Karlsruhe. (ib) 